\title{
Administering the Inclusiveness of Neglected Low-Income Urban Families to Access Healthcare Services: A Qualitative Inquiry
}

\author{
Chairun Nasirin ${ }^{1, *}$, Andries Lionardo ${ }^{2}$ \\ ${ }^{1}$ Department of Health Administration, College of Health Sciences (STIKES) Mataram, Indonesia \\ ${ }^{2}$ Universitas Sriwijaya, Palembang, Indonesia
}

Received June 16, 2021; Revised September 8, 2021; Accepted September 26, 2021

\section{Cite This Paper in the following Citation Styles}

(a): [1] Chairun Nasirin, Andries Lionardo, "Administering the Inclusiveness of Neglected Low-Income Urban Families to Access Healthcare Services: A Qualitative Inquiry," Universal Journal of Public Health, Vol. 9, No. 5, pp. 263 - 267, 2021. DOI: 10.13189/ujph.2021.090508.

(b): Chairun Nasirin, Andries Lionardo (2021). Administering the Inclusiveness of Neglected Low-Income Urban Families to Access Healthcare Services: A Qualitative Inquiry. Universal Journal of Public Health, 9(5), 263 - 267. DOI: 10.13189/ujph.2021.090508.

Copyright $\mathrm{C} 2021$ by authors, all rights reserved. Authors agree that this article remains permanently open access under the terms of the Creative Commons Attribution License 4.0 International License

\begin{abstract}
Purpose: This study aims to know the implementation of good performance of local governance in improving the quality of health administration, especially the future of neglected children who live in urban areas to access the health facilities provided by the Government. Method: This study uses a kind of naturalistic qualitative research aimed at obtaining an overview of the phenomenon that occurred in the neglected children in Mataram. Data collection is conducted through a depth interview of the key informant who has the relevance of knowledge that is relevant to the problem of neglected children. Result: The results of this study showed that the problem of neglected children is a real phenomenon in the city of Mataram. The issues faced by local governments regarding the difficulty of local governments to overcome health problems for neglected children. So that whenever child neglect has a severe health problem, they should have to ask compassion for other people to help. Conclusion: The issue of neglected children is a real phenomenon that generally occurs in urban areas, and neglected problems occur influenced by the poverty factor. The implementation of local government functions has not been running correctly. The social development planning of local government is not functioning optimally due to the lack of clarity regarding health policy for neglected children who have social problems in the urban area.
\end{abstract}

Keywords Health Administration, Empowerment, Neglected Children, Health Care

\section{Introduction}

The low-income people usually have more financial difficulties in accessing health services. It is undoubtedly related to the fewer number of professional health workers and insufficient medical health equipment that will impact the low quality of health care in the community [1]. The health program that has implications in the society, on the other hand, will inevitably affect the social policy that becomes an essential program of local government in improving public health services and enhances the welfare of the whole community [2]. Meanwhile, the social policy expected by the public should be in line with the administrative systems in the region, especially regarding neglected children from low-income families [3] [4].

Social phenomena related to neglected children do not only occur in Indonesia but also in almost part of all developing countries. The existence problem of neglect is due to urbanization, and the parents of neglect child expects to the government to have safe care program so that their child's life can be better in the future [5]. Neglected children is part of child abuse that leads to 
variety of consequence on child development [6]. Besides, the problem of problems occurs because parents cannot have a permanent home and do not have a stable work, so this problem is undoubtedly a trigger for families to ask their child to work on the street to suffice the economic needs for their families [7]. In line with the neglected problems, the studies conducted by Zufferey and Parkes [8] show that families have issues with neglected due to various conditions, such as financial problems, no permanent house for their families, and their parents have mental illness problems. On the other hand, although health development significantly contributes to improving people's welfare, social issues are still a difficult problem for governments in urban areas. These social problems happened due to poverty, neglect, disability, and the occurrence of behavioral problems such as parents have a dependence on gambling Zufferey \& Parkes [8] and, parents didn't have permanent homes because was damaged by a destructive and shallow earthquake, commonly known as Lombok earthquake on 5 August 2018 [9].

However, this problem is related to the survival of neglected children and the social gaps that occur in the community so that the government needs to give serious attention to realizing the social welfare of all communities [10]. Following the implied mandate in the Constitution of the Republic of Indonesia, article 34 stated that 'poor and neglected children are protected by the stated that this means that the government continuously expected to implement a variety of living welfare programs for the whole community. Therefore, to provide protection and respect for children as part of citizens who have the right to participate and be empowered them, and give protection to the neglected children. However, to prevent dehumanization, Nasirin and Lionardo [11] stated that the government needs real strategy and action to eliminate the dichotomy of government administration problems in addressing the issues of the displaced children to live better in the future. Neglected problems are generally experienced by girls whose parents are less economically capable and cannot empower themselves and their families [12]. This economic condition can undoubtedly be one of the essential variables in the process of formulation of policies relating to social and health. Therefore, the policymakers involved in formulating social-related policies for neglected children are undoubtedly inseparable from the socio-economic conditions.

\section{Literature Review}

The whole community needs the Government's presence in increasing the degree of healthy and prosperous lives as a process of community life in good governance. The importance of the concept of social services is undoubtedly closely related to the health care problems that the
Government will provide to its people as social security in improving health and well-being [13]. It is acknowledged that many sides of our daily lives are strictly related to the functioning of government administration policies relating to health and social welfare.

The implementation of social security programs must involve local governments to ensure that the application of social programs for people in the area can be better. According to Andriansyah et al. [14], there are several government roles in improving social security for the community, namely: (1) supervision of the implementation of the national social security system program, (2) provide an additional budget to contribute, either to the recipient of the assistance or other communities; (3) The determination of participants of the beneficiaries contribution (4) provision and management of health support facilities.

In addressing ethical governance issues, all government affairs must be undertaking by territorial Government authorities. The success of all such government programs is primarily not detached from the costs incurred from the regional financial budget sources $[15,16]$. Meanwhile, to improve the governance of both useful governance innovations is indispensable [17]. Therefore, the Government has to protect the community from the maladministration and the invasion of others to protect all communities from the Government's weakness in addressing the issue of administrative policies to improve good governance that can manage administration well.

The health problems of neglected children are the main phenomena faced by the health department. Besides that, the fulfillment of the rights and needs of the children must be following law No. 4 the year 1979 regarding the welfare of children and LAW No. 23 the year 2002 on child protection. The importance of local government in improving the well-being of the community aims to allow prosperity for all people to be fulfilled and increase the degree of health for the neglected children following the expectation of good governance.

Development through regional autonomy can undoubtedly provide opportunities for the region to be able to reorganize good governance in the area. The effectiveness of local governments is indeed not separate from the components of balance between improving social welfare and health efforts to enhance good government [18]. Therefore, in managing a good government is undoubtedly needed a strategy of community empowerment that can improve the welfare of the poor in urban areas [19]. With the enactment of Act number 22/1999 concerning autonomous regions, the government is empowered to be able to regulate government functions to manage the empowerment of children neglected. Based on the government policy, although Indonesia has many regions, all systems refer to the rules of the central government that must be implemented by each region. Hence, the policy arrangement will undoubtedly have an impact on the government administration in the area that 
governs the social, economic, and cultural problems needed in the effort to overcome health and social issues for children in the region.

The success of social welfare development, besides being determined by the quality of service, and can also be influenced by the system and direction of government policy and the provision of government-provided social services to the target group [20]. Then, strategies and planning to address health access issues for neglected children are government policies to solve social and health problems. Besides, various policies and programs need to develop continuously to create situations and conditions conducive to the development of child neglect, which is a constitutional mandate to educate the nation's children as an effort to build a better future of governance [21, 22].

\section{Method}

This research aims to explain and obtain an overview of the neglected children phenomenon studied deeply in the context of local government management. This study, therefore, uses a qualitative research type with a naturalistic approach. This option is based on the suitability of the nature of qualitative research that is flexible and has a mindset that is empirical induction, where everything in this research is determined from the result of the actual data collection at the research site.

To obtain valid data, researchers do some techniques such as depth interviews on informant that has relevance and knowledge relevant to the research problem namely: (1) management of the child protection agency; (2), and parents of abandoned children and abandoned children themselves.

Data collection is done in an integrative way and relevant to the focus of the research, and the formulation of research problems and objectives, using prevalent techniques, such as depth interviews, observation of participation, and documentation studies

\section{Results}

The studies show that almost every part of the economic centers in the city or in the tourist sites of Mataram city is often found neglected children who do their job activities. As for the areas that targeted the movements of neglected children, usually, they choose crowded public locations such as airport areas, malls, traditional markets, tourist areas, and in the other districts. The neglected children considered that the cities were strategic for them to offer handicraft services and products even though the activities undertaken by the abandoned children were deemed to be disturbing others. According to Dubois \& Milley [23], when many children are displaced, the surrounding social environment must make a protective effort or protection with the term parent patriae, which is a role that takes over the part of the government regarded as the legal protector of a citizen such as protecting health care for neglected children. However, neglected children in Mataram occur because of the condition of the community that is socially and economically experiencing problems, so that the role of the parent patriae (training board and social development department, 2015). In this case, the role and function of government becomes essential to deal with the phenomenon of displaced children in Mataram.

Neglected children are scattered in the tourist areas and public facilities in the city of Mataram, they are generally regarded as often disruptive order, and this is recognized by the city's own authorities. Based on data obtained from the regional development planning board (2015), the presence of disadvantaged groups, such as street workers, beggars, neglected children, and others. One example of the study finding happens in a tourist place like a beach. The neglected children do the activity like selling handicraft products to the visitor or foreigner, and the neglected children are often seen to disturb when the tourists are relaxing in restaurants or coffee shops. Consequently, often the children got a warning from the security not to sell the results of his crafts when foreign tourists while eating or in the location of which there is a sign of prohibition for merchants entering the area.

The phenomena were almost scattered in all regions of the West Nusa Tenggara province, and the high number of neglected children were found in the Eastern part of Lombok (2.574 children), then followed by the city of Mataram (3.854), and central Lombok (3.845). The phenomenon of neglected children is the second-largest community in comparison with other social problems, a total of 24,058 children. For detail, see Table 1.

Table 1. Number of social prosperity problem

\begin{tabular}{lccccc}
\hline Number of Social Problem & \multicolumn{5}{c}{ Regency (Area of Lombok) } \\
\hline & North & East & Mataram City & Central & West \\
\hline Neglect Children & 2.768 & 84.763 & 3.854 & 3.845 & 2.574 \\
\hline Neglected Old People & 5.947 & 17.869 & 5.358 & 8.584 & 2.761 \\
\hline Disabled Children & 1.324 & 3.330 & 421 & 3.904 & 1.324 \\
\hline Low-income families & 16.653 & 83.588 & 36.761 & 36.161 & 60.117 \\
\hline
\end{tabular}

Source: West Nusa Tenggara in Data 2015 
The results show that, generally, the neglected children found in Mataram due to physical problems and neglected emotional problems. The neglected problem due to the physical aspect is the failure of parents in fulfilling their children's basic needs, such as food, clothing, health, education, and housing. Meanwhile, the form of emotional problems for neglected children in the city of Mataram is the failure of parents in fulfilling the protection, warmth, attention, compassion, and guidance for his children worthily. Nevertheless, neglected children may also occur due to poor environmental factors.

Empowerment aims to create self-organizing and self-reliance setting capacities of the empowered communities [24]. The neglected community, then, has a close relationship with the government in enhancing sustainable development where empowerment is an essential aspect of bringing communities into dynamic economic, social, and ecological sustainability. The strategic environment owned by the local community, among others, includes health, economic, social, and environmental contexts [25].

The city of Mataram government also conducts the conception of neglected children that can be distinguished with children with other social problems. Mapping the understanding of abandoned children is not only done by the city government but also performed by the activists neglected children, such as the children protection agency west Nusa Tenggara. This shows that the phenomenon of neglected children is the concern of all people in the community.

This conceptual mapping of social issues demonstrates the efforts of the city government to address the problems of neglected children. This seriousness can be understood while seeing the development of the neglected children in Mataram City that is increasing rapidly and tends to be minimal in decline. The real leading cause of explaining the rapid growth of neglected children in Mataram is the problem of poverty. The issue of poverty in this area relies on the real issues that exist in the community. Based on community data with social matters in Mataram, the top position of the number of social problem communities in low-income families, with a total of 37,043 people and then followed by a community of neglected children of 24,058 people. Between the group of poor and neglected children have a relationship, and it is known that the poverty condition that most produce neglected children in the city of Mataram. It is based on the data of the number of low-income families in Mataram city, and there are 36,335 families in the category of poor or $45 \%$ of the total number of 81,364 family heads in Mataram City (medium Term development plan, 2010 - 2015).

The Mataram City government has identified several internal and external factors that cause neglected children and other social problems. The government of Mataram city determines that internal and external conditions cause the purpose of the aspect of neglected children and other social issues. Internal conditions relate to neglect child poverty who have limitations on ability concerning physical barriers, intellectuals, mental-emotional, spiritual, social-psychological, skill, and assets. Furthermore, some factors of poverty in urban areas, including lack of social protection services for the community, the difficulty of gaining access to health, lack of security protection for communities in the urban area, many dry farms, and society still considers that welfare and social issues are the responsibility of the Government (Development planning Board Mataram, 2015). According to Qi \& Wu [26] stated that neglected children often influenced by poverty factors and other variables, such as education, health, nutrition, socio-cultural issues, and protection.

The results of the observational findings of this study show that poverty occurred in Mataram due to the geographical factors, education, and change of the function of agricultural land into office buildings. Furthermore, some other findings regarding the neglected phenomenon in Mataram can be expressed in some essential points. First, the aspect of neglected children is a real phenomenon and quite crucial in quantity and quality for development challenges in the city of Mataram. Second, the element of displaced children in Mataram has a clear and distinct character and differentiated with children with other social problems, such as street children, naughty children, and children with violent victims. Third, there is a driving factor in the condition of a neglected children phenomenon or the existence of internal conditions that force the neglected children as well as the presence of other external conditions that are capable of addressing health issues related to the social problems of neglected children.

\section{Conclusions}

The phenomenon of neglected children is a real phenomenon in the city of Mataram, and the aspect of neglected children found in large numbers in the city of Mataram, and its development is heavily influenced by the poverty factor so that it becomes a significant factor in the occurrence of social welfare issues so that the trigger factor arises and the development of abandoned children in the city of Mataram

The implementation of local government functions, both at the planning and implementation stage, is not optimal. Besides, the purpose of regional government planning in Mataram city is caused by the functioning of the Government's role in addressing health access problems for neglected children because the government still has a budget dependency on the central government.

\section{REFERENCES}

[1] X Liu, F Wang, X Ding, Y Chen, L Wang, "Strengthening the maternal and child health system in remote and 
low-income areas through multilevel governmental collaboration: a case study from Nujiang Prefecture in China," Public health, vol. 178, pp. 23-30, 2020.

[2] Ross C Brownson, Jamie F Chriqui, Katherine A Stamatakis, "Understanding evidence-based public health policy," American journal of public health, vol. 99, pp. 1576-1583, 2009.

[3] Hurmuz Naeim David, "Evaluation of the effectiveness of the modern system of public administration in Syria and the possibility of introducing change management," Public Administration Issues, vol. 6, pp. 107-118, 2018.

[4] Munezero Florence, Ahanhanzo Glele Yolaine, Sossa Jerome Charles, Bazira Leodegard, "Hospital Information System in the Context of the Use of Electronic Medical Record in Burundi," Universal Journal of Public Health, vol. 9, no. 2, pp. 94 - 101, 2021. DOI: 10.13189/ujph.2021.090208.

[5] Azhar N, Ulwan, "The Role of Young Entrepreneurs in Labor Absorptions and its Implications to Family Economic Resilience," Research Horizon, vol. 1, no. 1, pp. 16-27, 2021.

[6] Mara Silvia Pasian, Priscila Benitez, Carl Lacharité, "Child neglect and poverty: A Brazilian study," Children and Youth Services Review, vol. 108, no. 104655, 2020.

[7] Marya Viorst Gwadz, Karla Gostnell, Carol Smolenski, Brian Willis, David Nish, Theresa C Nolan, Maya Tharaken Amanda S Ritchie, "The initiation of homeless youth into the street economy," Journal of adolescence, vol. 32, pp. $357-377,2009$.

[8] Carole Zufferey, Amy Parkes, "Family homelessness in regional and urban contexts: Service provider perspectives," Journal of Rural Studies, vol. 70, pp. 1-8, 2019.

[9] Daniel, Félix, Jorge M Branco, Artur Feio, "Temporary housing after disasters: A state of the art survey," Habitat International, vol. 40, pp. 136-141, 2013.

[10] Jiun-Hao Wang, "Happiness and Social Exclusion of Indigenous Peoples in Taiwan-A Social Sustainability Perspective," PloS one, vol.10, no. e0118305, 2015.

[11] Chairun Nasirin, Andries Lionardo, "Decentralization, Public Services and Neglected Children in Mataram City, West Nusa Tenggara," Research Horizon, vol. 1, no. 2, pp. 55-61, 2021.

[12] Jeretta Horn Nord, Fatih Çetin, Özlem Atay, Joanna Paliszkiewicz, "Examining the impact of social technologies on empowerment and economic development," International Journal of Information Management, vol. 36, pp. 1101-1110, 2016.

[13]J Mac McCullough, "Local health and social services expenditures: an empirical typology of local government spending," Preventive medicine, vol. 105, pp. 66-72, 2017.

[14] Andriansyah, Endang Sulastri, Evi Satispi, "The Role of Government Policies in Environmental Management," Research Horizon, vo. 1, no. 3, pp. 86-93, 2021.
[15] Nunuy Nur Afiah, Peny Cahaya Azwari, "The effect of the implementation of government internal control system (GICS) on the quality of financial reporting of the local government and its impact on the principles of good governance: A research in district, city, and provincial government in South Sumatera," Procedia-Social and Behavioral Sciences, vol. 211, pp. 811-818, 2015.

[16] George Cairns, George Wright, Ron Bradfield, Kees Van Der Heijden, George Burt, "Exploring e-government futures through the application of scenario planning," Technological Forecasting and Social Change, vol. 71, pp. 217-238, 2004.

[17] Kornelia Konrad, Knud Böhle, "Socio-technical futures and the governance of innovation processes-an introduction to the special issue," Futures, vol. 109, pp. 101-107, 2019.

[18] Anis Omri, Nejah Ben Mabrouk, "Good governance for sustainable development goals: Getting ahead of the pack or falling behind?," Environmental Impact Assessment Review, vol. 83 , no. $106388,2020$.

[19] Anuradha Joshi, "Legal empowerment and social accountability: Complementary strategies toward rights-based development in health?," World Development, vol. 99, pp. 160-172, 2017

[20]Lanndon Ocampo, Jovir Alinsub, Ruselle Anne Casul, Germellie Enquig, Mitzi Luar, Noche Panuncillon, Miriam Bongo, Christine Omela Ocampo, "Public service quality evaluation with SERVQUAL and AHP-TOPSIS: A case of Philippine government agencies," Socio-Economic Planning Sciences, vol. 68, no. 100604, 2019.

[21] Mykola Zhurba, Yuliia Bokhonkova, Dmytro Marchenko, Nataliia Buhaiova, Marharyta Zhurba, "COVID-19 and Student Health Care in Ukraine: Do Public Decisions Meet Student Needs?," Universal Journal of Public Health, vol. 9 , no. 2, pp. 67 - 74, 2021. DOI: 10.13189/ujph.2021.090205.

[22] Gonzalo Castañeda, Florian Chávez-Juárez, Omar A Guerrero, "How do governments determine policy priorities? Studying development strategies through spillover networks," Journal of Economic Behavior \& Organization, vol. 154, pp. 335-361, 2018

[23] Brenda L Dubois, Karla K. Miley, "Social Work: An Empowering. Profession,” USA: Allyn \& Bacon, 1992.

[24]David Clark, Rebekah Southern, Julian Beer, "Rural governance, community empowerment and the new institutionalism: A case study of the Isle of Wight," Journal of Rural Studies, vol. 23, pp. 254-266, 2007.

[25] Andrew M Subica, Cheryl T Grills, Sandra Villanueva, Jason A Douglas, "Community organizing for healthier communities: environmental and policy outcomes of a national initiative," American journal of preventive medicine, vol. 51, pp. 916-925, 2016.

[26] Di Qi, Yichao Wu, "The extent and risk factors of child poverty in urban China-What can be done for realising the Chinese government goal of eradicating poverty before 2020," Children and Youth Services Review, vol. 63, pp. 74-82, 2016. 